Chapter 2

\title{
Morphology Characterization of Pitting Corrosion on Sensitized Austenitic Stainless Steel by Digital Image Analysis
}

\author{
Rosinei Batista Ribeiro, Gilbert Silva, \\ Antônio Henriques Jr. Araujo, \\ Nelson Tavares Matias, \\ José Wilson De Jesus Silva and \\ Bianca Siqueira Martins Domingos
}

Additional information is available at the end of the chapter

http://dx.doi.org/10.5772/57256

\section{Introduction}

Austenitic stainless steels are selected for corrosion resistance to the atmosphere and a vast variety of chemical products. This resistance is related to the formation of a thin and adherent oxide layer (mainly $\mathrm{Cr}_{2} \mathrm{O}_{3}$ ), which protects the surface against aggressive environments. The most common austenitic steels are iron-chromium-nickel alloys and they are widely known as the 300 series [1,2]. These alloys usually contain between 16 and $30 \mathrm{wt} \%$ chromium, from 8 to $20 \%$ nickel and from 0.03 to $0.1 \%$ carbon. With increasing chromium and nickel contents, these steels become increasingly resistant to pitting corrosion. However, higher concentrations of these alloying elements result in lower carbon solubility and carbide segregation [3,4]. Heat treatments, whether intentional or accidental, may provoke carbide precipitation at grain boundaries, often by causing steel to become susceptible to intergranular corrosion. In order to minimize carbide precipitation and prevent sensitization, austenitic steels are frequently subjected to high-temperature solution treatment, commonly termed quench-annealing $[5,6]$. Pitting corrosion is observed in austenitic steels exposed to aqueous media containing chloride ions. This phenomenon almost always starts in anodic MnS inclusions and chromium-depleted zone adjacent to cathodic $\mathrm{M}_{23} \mathrm{C}_{6}(\mathrm{M}=\mathrm{Cr}$ or $\mathrm{Mo})$ precipitates, and it progresses inwards in intergranular or transgranular direction depending mainly on the steel microstructure $[7,8]$. 
Many studies have been focused on the pit initiation and propagation mechanisms of these steels in chloride media, but relatively a few authors have considered the morphologic characteristics of pitting corrosion $[9,10]$. It should be noted that pit growth rate depends on potential distribution inside the pit, which is determined by pit shape, especially by their width/depth aspect ratio [11,12]. For pits initiated by electrochemical experiments, the pit depth or pit radius dependence on the immersion time $(t)$ may be expressed by the equation $k\left(t-t_{i}\right)^{n}$, where $t_{i}$ is the induction period, $k>0$ and $1 / 3 \leq n \leq 1$ are empirical constants which depend on chloride concentration, pits shape and experimental conditions inherent of electrochemical methods $[13,14]$. Pits are usually modeled as having cylindrical, hemispherical or conical shapes, but in practice, they have a tendency to assume an irregular or not welldefined geometry associated with increasing size [15]. Therefore, equations, developed with these assumptions about shape, must be considered as only rough approximations.

In this study, a method based on image analysis has been used for the morphology characterization of pitting corrosion on sensitized 310S steel. For this purpose, pits have been initiated by Salt Spray exposure, and their temporal evolution has been examined by reflected light microscopy.

\section{Materials and methods}

As-received 310S plates [16] have been submitted to three solution heat treatment routines: heating up to $1065^{\circ} \mathrm{C}$ during $1 \mathrm{~h}$ and air cooling (condition I); heating up to $1065^{\circ} \mathrm{C}$ during $1 \mathrm{~h}$ and air cooling followed by reheating up to $670^{\circ} \mathrm{C}$ during $5 \mathrm{~h}$ and again air cooling (condition II); heating up to $1065^{\circ} \mathrm{C}$ during $1 \mathrm{~h}$ and air cooling followed by reheating up to $620^{\circ} \mathrm{C}$ during $24 \mathrm{~h}$ and again air cooling (condition III). The main purpose for annealing has been to produce a recrystallized microstructure with a uniform grain size and for dissolving detrimental chromium carbide precipitates. Then, a slow cooling or reheating within the range $550^{\circ}-800^{\circ} \mathrm{C}$ will lead to the rejection of carbon from solution, usually as the chromium-rich carbide, even when the carbon content of the steel is very low $(<0.05 \mathrm{wt} \%)$.

Specimens have been mechanically polished and their microstructure have been chemically etched with the following solution: $10 \mathrm{~mL} \mathrm{HF}(48 \%)+10 \mathrm{~mL} \mathrm{HNO}_{3}(65 \%)+15 \mathrm{~mL} \mathrm{HCl}(35 \%)$. Surfaces have been examined before and after Salt Spray tests [17] using a method of image analysis based on reflected light microscopy (LM). Images have been captured using a Nikon Epiphot 200 inverted metallurgical microscope coupled to a Diagnostic Instruments Insight Color QE digital camera. The NIH freeware program Image J [18] has been used for image processing, and a macro program has been developed to execute all processing and analysis steps. Quantitative parameters such as area at pit mouths, pit density and corroded area have been systematically determinate. Additionally, SEM and EDS combined techniques have been used to identify elemental composition of grains and grain boundaries. This surface analysis has been carried out using a scanning electron microscope Leica Stereoscan 440 with a coupled energy dispersive spectrometer Oxford Link Exl II.

Pits morphological characteristics have been determined by specimens vertical sectioning, under low load and rotation in a precision saw, followed by fine grinding and polishing. To ensure low deformation of profile region, corroded surfaces have been covered with an epoxy 
resin before cutting and mounting with phenolic resin for mechanical polishing. Analysis of pits has been based mainly on rectangularity or area-box $(\mathrm{AB})$ shape parameter, defined as the ratio between pit area and minor surrounding rectangle area which encloses pit [19]. $A B$ parameter is an effective geometry descriptor, permitting clear separation among conical pits $(0.5<\mathrm{AB}<0.53)$, spherical or hemispherical pits $(0.72<\mathrm{AB}<0.86)$ and cylindrical pits $(\mathrm{AB} \approx$ 1.0). Figure 1 summarizes the class for morphological analysis.

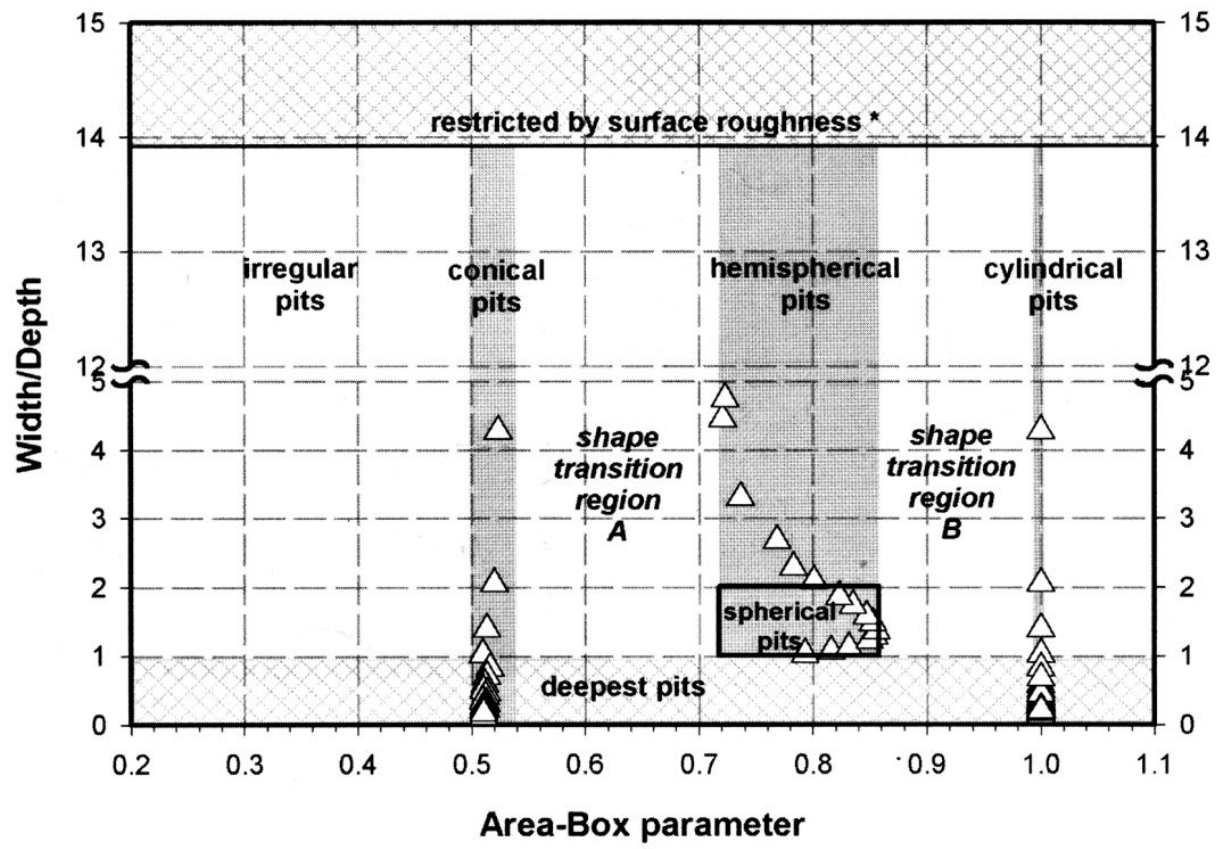

Figure 1. Diagram used for pit geometry classification. Width/depth aspect ratio versus area-box parameter.

Transition regions A (near-conical or near-hemispherical pits) and B (near-hemispherical or near-cylindrical pits) represent pits that can evolve the best-defined geometries. Irregular pits (without geometric elements) present $\mathrm{AB}$ values lower than 0.5. To determine pits size, both pit width and depth, the same rectangle above mentioned has been used. A representative number (60) of $1600 \times 1200 \times 8$ bit digital images under bright-field xenon-arc illumination has been obtained for each specimen.

\section{Results and discussion}

Morphological and microstructural analysis has been carried out before and after Salt Spray test. Before corrosion test (Figures 2 (a) - (c), conditions I, II and III exhibit similar characteristics: a non-homogeneous microstructure with an austenite phase, different orientation grains, 
carbide precipitates and some holes probably provoked during the mechanical processing and metallographic preparation of steel.
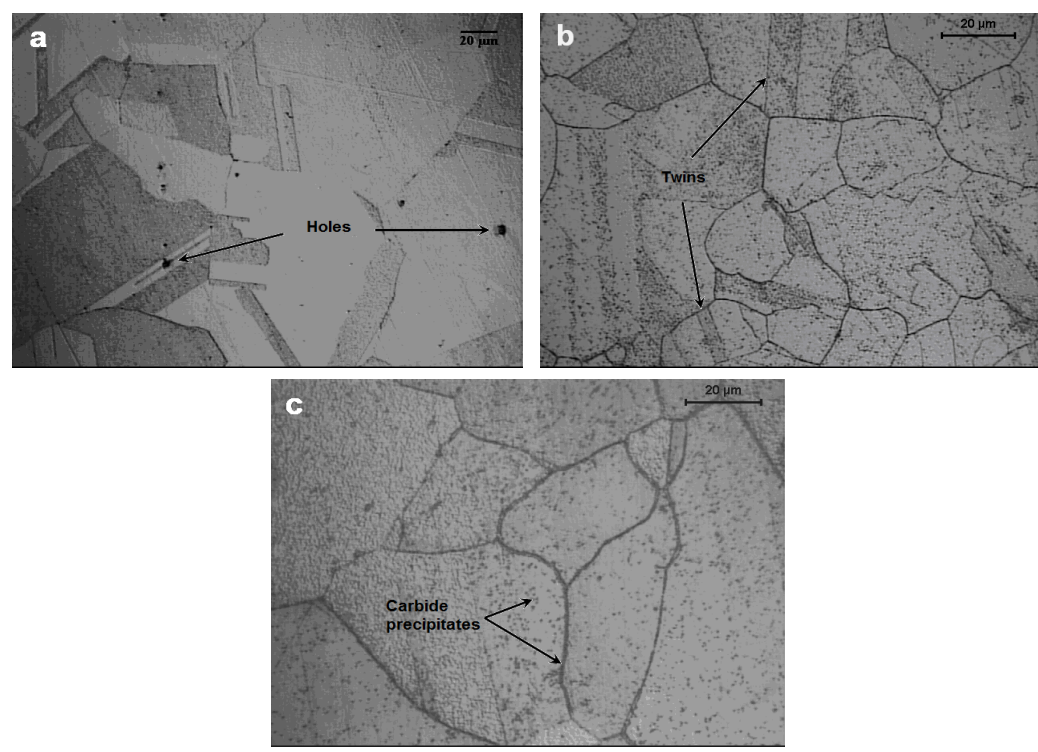

Figure 2. LM micrographs of 310 S sensitized before Salt Spray test: a) condition I, b) condition II and c) condition III.

Austenite phase is present as equiaxed grains, many of which contain annealing twins. These twins are identified as bands with parallel sides and are formed when changes in the striking of atoms on close-packed (111) planes occur during recrystallization and grain growth [20]. EDS semi-quantitative analysis on grain and grain boundary of condition II is showed in Figure 3 (a) and (b).
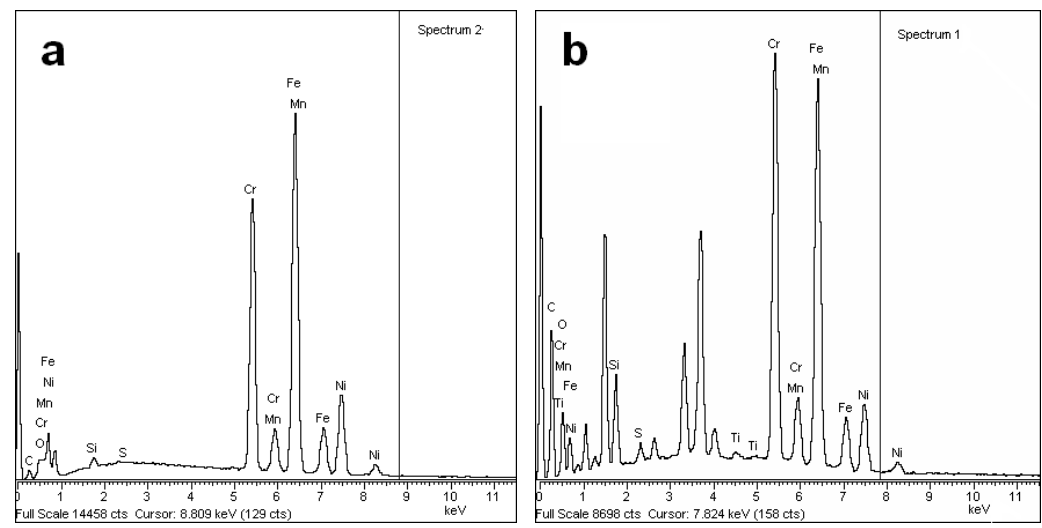

Figure 3. EDS semi-quantitative analysis upon the $310 \mathrm{~S}$ in condition II: a) grain and b) precipitate in grain boundary. 
The most significant results are absence of molybdenum in steel and enrichment of chromium in precipitates on grain boundary. One explanation that the Mo peak was not detected is that it probably merges with the Ti peak. Also it may be that the analysis has been punctual, and not general.

After corrosion test, surfaces have revealed pits of different shapes and sizes. Table 1 permits to compare statistical parameters measured on exposed surfaces. For all heat treatment conditions, low values of corroded areas suggest there is a low probability of pit superposition during the exposure period.

\begin{tabular}{ccccccc}
\hline Parameter & Heat Treatment & \multicolumn{5}{c}{ Exposure Period (h) } \\
\hline Pit density & I & 48 & 120 & 168 & 216 & 312 \\
\hline$\left(\mathrm{mm}^{-2}\right)$ & II & 15.98 & 28.02 & 39.76 & 200.09 & 378.06 \\
\hline Corroded area & III & 9.02 & 10.45 & 15.34 & 14.09 & 19.99 \\
\hline$(\%)$ & II & 0.08 & 0.20 & 0.44 & 0.50 & 2.40 \\
\hline Area at mouth & III & 0.04 & 0.10 & 0.55 & 0.90 & 1.89 \\
\hline$\left(\mu m^{2}\right)$ & I & 10.09 & 11.98 & 12.65 & 12.32 & 13.07 \\
\hline
\end{tabular}

Table 1. Variation of pitting corrosion parameters measured on exposed surfaces

Thus, the temporal variation in pit density and pit area may be directly related to the rates of pit nucleation and two-dimensional growth, respectively. This way, nucleation rate has remained approximately constant for conditions II and III, and it has increased for condition I. In this last condition, the pits growth is slower. These facts are mainly related with a number of anodic sites and anodic/cathodic area ratio variation during exposure period.

Figure 4a-c shows cross-section images of sensitized steels after 312 h of Salt Spray test, according to ASTM B117 - 11 [17]. The choice of time interval is empirical and is based on the following relationship: with increasing exposure time, changes occur in corrosion resistance behavior, in distribution and in morphology of pits at material as received and treated.

Conditions I and II, pits are nucleated in grains and grain boundaries, while in condition III, pits are preferentially nucleated in boundaries of small grains. Generally, carbides are too fine to be resolved by reflected light microscope, but are indirectly revealed by deep etching of affected grain boundaries (Figure 4c). Pits classification and distribution have been determined from cross-section images. Table 2 indicates that for all conditions: (i) the hemispherical, near- 

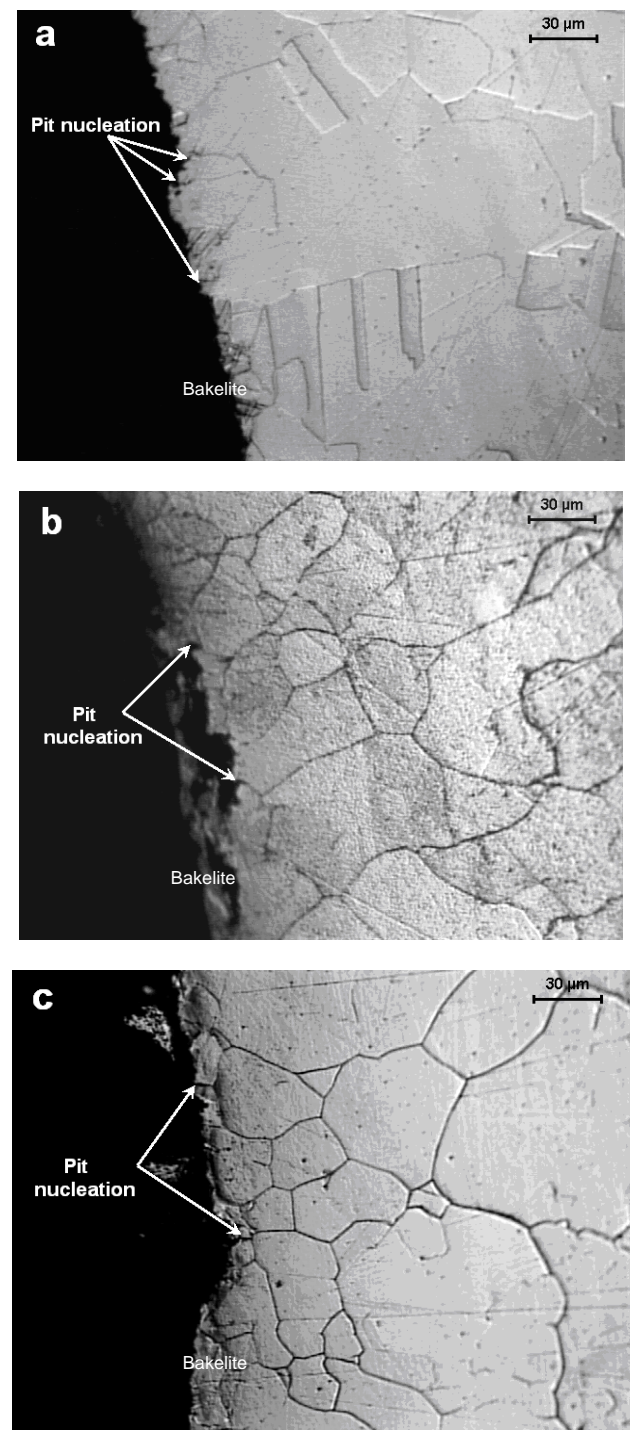

Figure 4. Cross-section images of 310 s sensitized after 312 h of Salt Spray test: a) condition I, b) condition II and c) condition III.

hemispherical, near-conical and near-cylindrical pits represent more than $80 \%$ of the pit population; (ii) they appear not to undergo geometric transition associated with an increasing exposure period; (iii) pits with regular geometry represent less than $45 \%$ of pit population; (iv) cylindrical pits are absent. This geometry distribution may be attributed to similar microstructural characteristics of different heat treatment conditions. 


\begin{tabular}{|c|c|c|c|c|c|c|}
\hline \multirow[t]{2}{*}{ Pit Geometry } & \multirow[t]{2}{*}{ Heat Treatment } & \multicolumn{5}{|c|}{ Exposure Period (h) } \\
\hline & & 48 & 120 & 168 & 216 & 312 \\
\hline & I & 6.41 & 0.67 & 0.66 & 4.19 & 0.00 \\
\hline \multirow[t]{3}{*}{ Irregular (\%) } & II & 1.71 & 7.43 & 3.75 & 5.36 & 6.67 \\
\hline & III & 0.00 & 3.17 & 15.87 & 6.44 & 12.30 \\
\hline & I & 1.28 & 4.67 & 1.32 & 2.80 & 1.23 \\
\hline \multirow[t]{2}{*}{ Conical (\%) } & II & 0.00 & 6.93 & 5.00 & 2.68 & 1.02 \\
\hline & III & 0.00 & 2.08 & 2.59 & 13.30 & 6.56 \\
\hline Transition & I & 7.70 & 54.66 & 14.47 & 26.57 & 3.47 \\
\hline \multirow[t]{3}{*}{ Region A (\%) } & ॥ & 20.50 & 24.36 & 24.16 & 27.68 & 30.45 \\
\hline & III & 18.14 & 27.09 & 26.98 & 61.80 & 39.33 \\
\hline & I & 19.23 & 29.33 & 28.29 & 17.48 & 20.99 \\
\hline \multirow[t]{2}{*}{ Hemispherical (\%) } & II & 23.08 & 18.80 & 36.71 & 41.96 & 42.56 \\
\hline & III & 24.29 & 28.40 & 29.16 & 15.88 & 24.60 \\
\hline Transition & I & 65.38 & 10.67 & 55.26 & 48.96 & 74.31 \\
\hline \multirow[t]{3}{*}{ Region B (\%) } & ॥ & 54.71 & 42.48 & 30.38 & 22.32 & 19.30 \\
\hline & III & 57.57 & 39.26 & 25.40 & 2.58 & 17.21 \\
\hline & I & 0.00 & 0.00 & 0.00 & 0.00 & 0.00 \\
\hline \multirow[t]{2}{*}{ Cylindrical (\%) } & ॥ & 0.00 & 0.00 & 0.00 & 0.00 & 0.00 \\
\hline & III & 0.00 & 0.00 & 0.00 & 0.00 & 0.00 \\
\hline
\end{tabular}

Table 2. Classification and distribution of pits percentages

Table 3 shows pit width and depth distributions. To diminish influence of pre-existing holes and pits superposition on the count and statistical treatment of data, it has been replaced the mean values by the medians [21-28].

Detailed analysis in this table indicates that for all conditions: (i) for each exposure period, width inside pit is in good agreement with the width at pit mouth estimated from Table 1 (supposing circular mouth); (ii) pit depth rapidly increases during the first 48 hours of Salt Spray exposure, and then it is apparently stabilized; (iii) pits are deeper than wide, which suggests that metal dissolution rate is higher at pit bottom than at the pit wall; (iv) pit depth increases from Transition regions B to Irregular geometry; (v) irregular pits are also the widest ones.

This class of pits may have nucleated in holes, Figure 2 (a), and they have grown by an intergranular way and/or they have nucleated in boundaries of small grains and during their growth provoke grains separation, as showed in Figures $4 \mathrm{~b}$ and $4 \mathrm{c}$. Although irregular pits represent a small percent of pitpopulation, in practice themaximum depthvaluesarevery importantbecause the deepest pits can initiate cracks when steel is subjected to mechanical stress. 


\begin{tabular}{|c|c|c|c|c|c|c|c|}
\hline \multirow[t]{2}{*}{ Pit Geometry } & \multirow[t]{2}{*}{ Heat Treatment } & \multirow{2}{*}{$\begin{array}{c}\text { Parameter } \\
(\mu \mathrm{m})\end{array}$} & \multicolumn{5}{|c|}{ Exposure Period (h) } \\
\hline & & & 48 & 120 & 168 & 216 & 312 \\
\hline & 1 & Width & 7.12 & 14.88 & 11.73 & 5.74 & - \\
\hline & 1 & Depth & 33.17 & 27.19 & 16.31 & 27.47 & - \\
\hline \multirow{6}{*}{ Irregular } & \multirow{2}{*}{ ॥ } & Width & 7.29 & 9.52 & 6.01 & 7.77 & 8.15 \\
\hline & & Depth & 11.01 & 9.80 & 23.32 & 15.19 & 25.26 \\
\hline & \multirow{2}{*}{ III } & Width & - & 6.65 & 6.35 & 7.04 & 6.96 \\
\hline & & Depth & - & 17.15 & 27.79 & 7.15 & 12.84 \\
\hline & \multirow{2}{*}{ I } & Width & 4.58 & 9.01 & 6.86 & 4.65 & 4.72 \\
\hline & & Depth & 21.46 & 14.59 & 6.29 & 11.77 & 18.60 \\
\hline \multirow{4}{*}{ Conical } & \multirow{2}{*}{ ॥ } & Width & - & 6.51 & 4.79 & 4.57 & 5.02 \\
\hline & & Depth & - & 6.88 & 16.81 & 13.02 & 15.29 \\
\hline & \multirow{2}{*}{ III } & Width & - & 4.86 & 5.01 & 6.30 & 6.35 \\
\hline & & Depth & - & 20.62 & 19.60 & 6.46 & 8.78 \\
\hline \multirow{2}{*}{ Transition } & \multirow{2}{*}{ I } & Width & 4.74 & 6.89 & 6.64 & 4.38 & 6.34 \\
\hline & & Depth & 14.02 & 7.34 & 8.57 & 14.64 & 14.31 \\
\hline \multirow{6}{*}{ Region A } & \multirow{2}{*}{ II } & Width & 5.50 & 6.66 & 4.39 & 5.53 & 6.22 \\
\hline & & Depth & 10.50 & 6.88 & 15.00 & 10.68 & 12.99 \\
\hline & \multirow{2}{*}{ III } & Width & 4.37 & 5.71 & 4.17 & 6.06 & 5.80 \\
\hline & & Depth & 20.15 & 9.65 & 13.43 & 6.18 & 7.91 \\
\hline & \multirow{2}{*}{ I } & Width & 4.82 & 6.02 & 5.89 & 3.91 & 3.67 \\
\hline & & Depth & 11.19 & 6.85 & 6.99 & 8.66 & 14.02 \\
\hline \multirow{4}{*}{ Hemispherical } & \multirow{2}{*}{ ॥ } & Width & 5.99 & 5.76 & 5.07 & 5.55 & 6.38 \\
\hline & & Depth & 9.16 & 6.32 & 10.13 & 7.54 & 10.28 \\
\hline & \multirow{2}{*}{ III } & Width & 3.24 & 4.97 & 5.01 & 5.54 & 4.88 \\
\hline & & Depth & 13.09 & 8.33 & 9.48 & 5.59 & 7.00 \\
\hline \multirow{2}{*}{ Transition } & \multirow{2}{*}{ I } & Width & 5.05 & 5.54 & 5.16 & 4.74 & 4.78 \\
\hline & & Depth & 5.40 & 5.21 & 4.73 & 5.16 & 5.91 \\
\hline \multirow{6}{*}{ Region B } & \multirow{2}{*}{ ॥ } & Width & 5.65 & 4.52 & 6.60 & 6.36 & 6.37 \\
\hline & & Depth & 6.30 & 5.29 & 7.39 & 6.51 & 7.55 \\
\hline & \multirow{2}{*}{ III } & Width & 4.79 & 5.10 & 5.12 & 3.19 & 4.72 \\
\hline & & Depth & 5.64 & 6.01 & 6.14 & 5.98 & 4.91 \\
\hline & \multirow{2}{*}{1} & Width & - & - & - & - & - \\
\hline & & Depth & - & - & - & - & - \\
\hline Glindrical & $\|$ & Width & - & - & - & - & - \\
\hline cyminted & 11 & Depth & - & - & - & - & - \\
\hline & $\mid \|$ & Width & - & - & - & - & - \\
\hline & III & Depth & - & - & - & - & - \\
\hline
\end{tabular}

Table 3. Variation of pit width and depth with increasing exposure period 


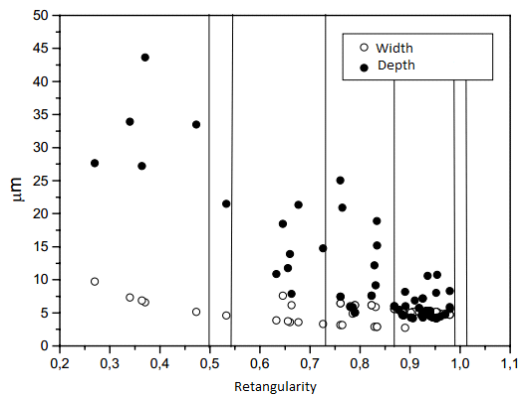

(a)

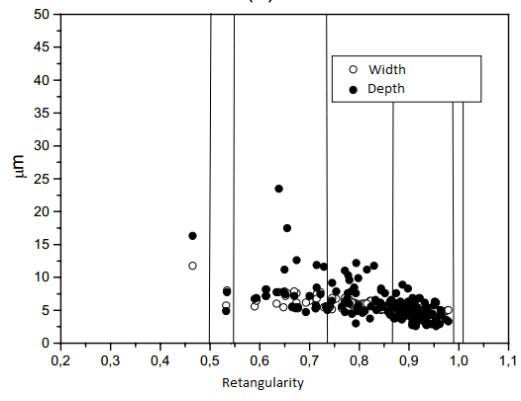

(c)

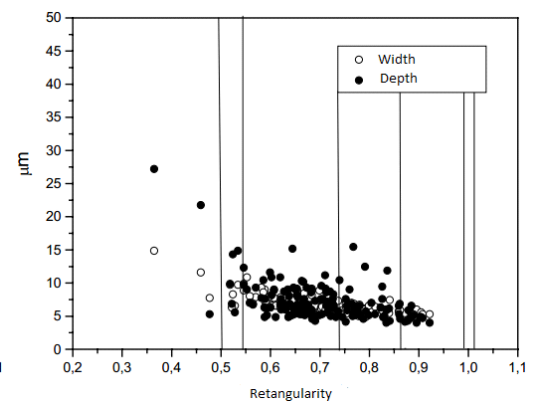

(b)

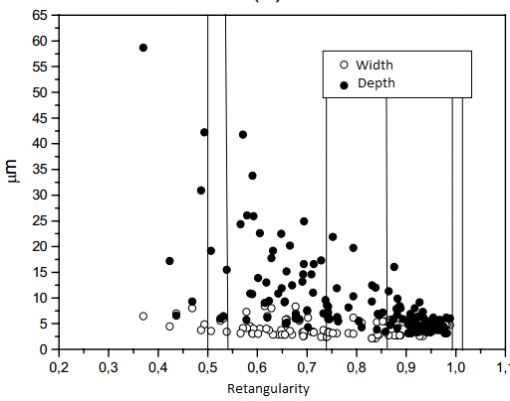

(d)

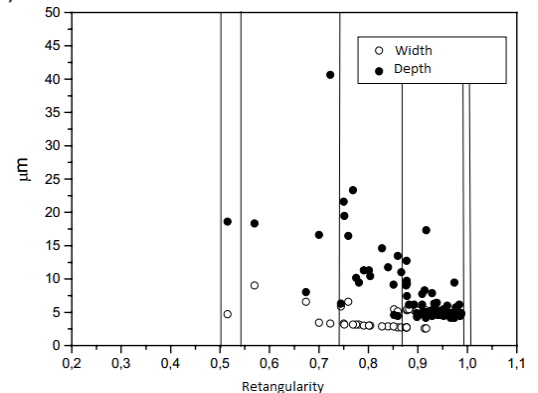

(e)

Figure 5. Size of pits formed on the surface of stainless steel $310 \mathrm{~S}$ treated $1065^{\circ} \mathrm{C}$ for 1 hour and cooled in air, after being subjected to corrosion testing via salt spray (a) 48 hours, (b) 120 hours (c) 168 hours, (d) 216 hours (e) 312 hours

The Figures 5 (a), (b), (c), (d) and (e) show the following order in the median size of the width and depth associated with the morphology of pits: irregular $>$ conic $>$ transition $\mathrm{A}>\mathrm{Hemi}-$ sphere > B transition; it was not observed the existence of cylindrical pits in the system.

The pits are more profound (around 3 times) than wide and growing preferably in depth. The longer the exposure time, the greater the depth of pits between different morphologies of pits (irregular: $33.17 \mu \mathrm{m}$ and conic: $18.60 \mu \mathrm{m}$ in 312 hours and irregular: $27.47 \mu \mathrm{m}$ in 48 hours 33.17 $\mu \mathrm{m}$ in 312 hours). 
The formation of pitting corrosion in stainless steel $310 \mathrm{~S}$ revealed differences, through association with the morphology, distribution, size and growth trend that govern all temporal evolution of pits and their interface (grain boundary and morphology of the precipitate).

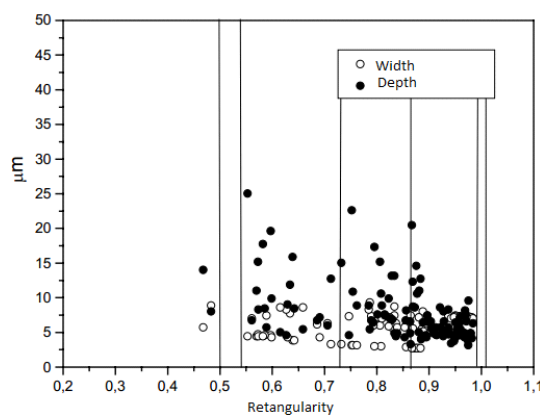

(a)

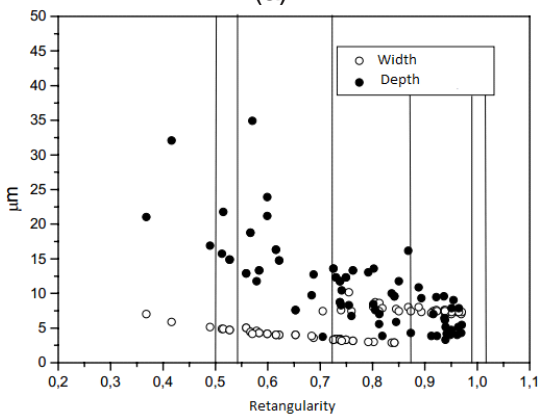

(c)

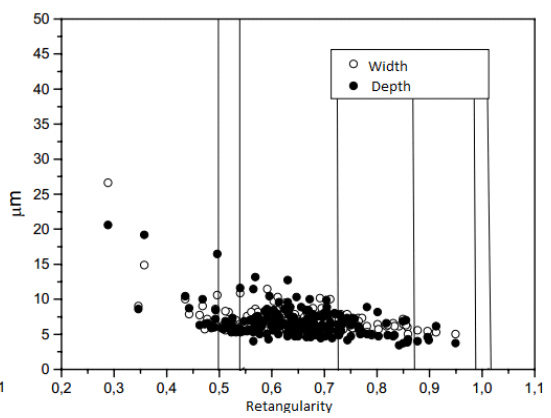

(b)

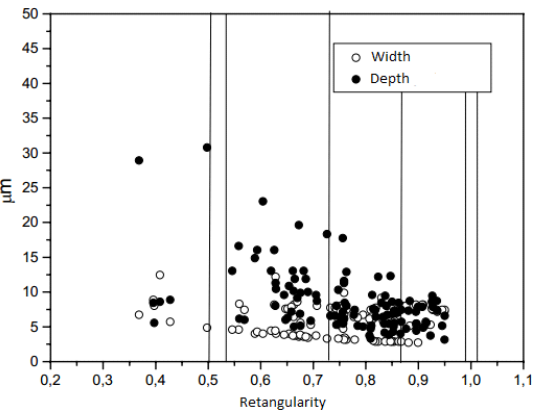

(d)

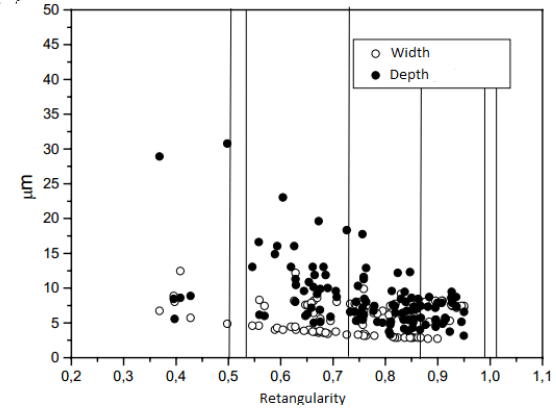

(e)

Figure 6. Size of pits formed on the surface of stainless steel $310 \mathrm{~S}$ treated $670^{\circ} \mathrm{C}$ for 5 hours and cooled in air, after being subjected to corrosion testing via the salt spray (a) 48 hours, (b) 120 hours (c) 168 hours, (d) 216 hours (e) 312 hours

In Figure 6, it is shown the following distribution and classification of pits: hemispherical > transition region $\mathrm{A}>$ transition region $\mathrm{B}>$ irregular $>$ conical. The pits are present in larger 
quantities in transition region B and hemispheric, there is virtually no evidence of presence and evolution of cylindrical pits in the system.

It is concluded that the distribution and classification of pits in stainless steel $310 \mathrm{~S}$ have the following trends: hemispheric $>$ transition region $\mathrm{B}>$ transition region $\mathrm{A}>$ conical $>$ irregular, sometimes, transition region $\mathrm{B}>$ hemispheric $>$ transition region $\mathrm{A}>$ conical $>$ irregular.

There was no presence of cylindrical pits in the system. The temporal evolution of the parameters that govern the distribution of pits is similar in stainless steel 310S when treated

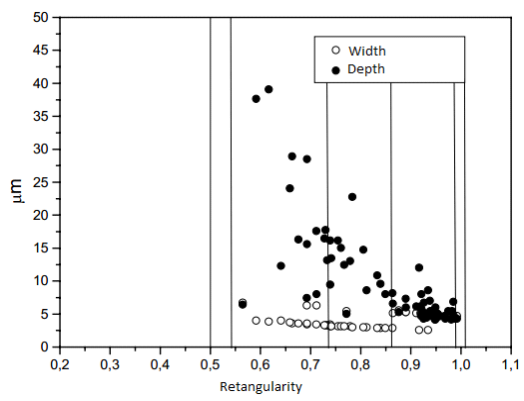

(a)

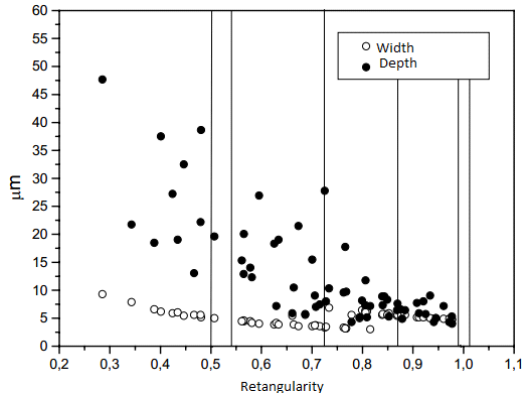

(c)

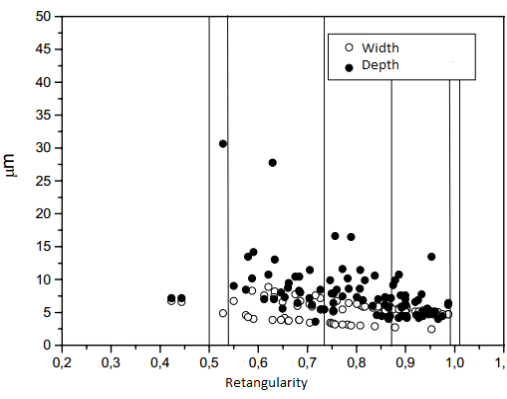

(b)

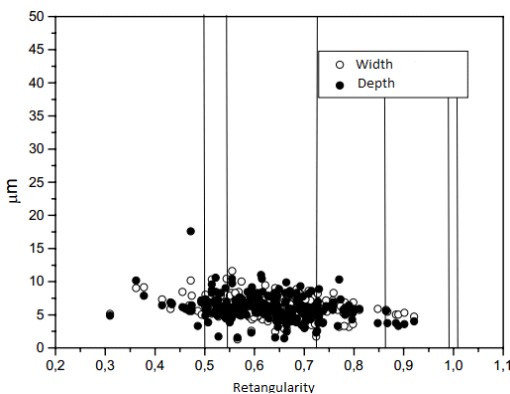

(d)

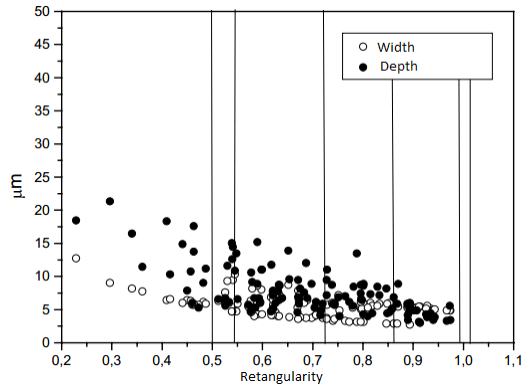

(e)

Figure 7. Size of pits formed on the surface of stainless steel $310 \mathrm{~S}$ treated $620^{\circ} \mathrm{C}$ for 24 hours and cooled in air, after being subjected to corrosion testing via the salt spray (a) 48 hours, (b) 120 hours (c) 168 hours, (d) 216 hours (e) 312 hours 
in the temperature range $620^{\circ} \mathrm{C}-670^{\circ} \mathrm{C}$. By increasing the exposure time, there is increased occurrence of pits and hemispherical in the transition region $\mathrm{A}$, but the time course is similar in steel when treated at $1065^{\circ} \mathrm{C}$ for 1 hour and air-cooled to $820^{\circ} \mathrm{C}$ for 1 hour and air-cooled.

Changes in the distributions have been observed, namely an increase in the number of pits in the transition region and the irregular geometries and the decrease in the transition region $\mathrm{B}$ in the steel in the as received and treated at $1065^{\circ} \mathrm{C}$ for 1 hour and cold water and ice.

Figure 7 presents the following order in the median size of the width and depth associated with morphology of pits: irregular $>$ conical $>$ transition $>$ hemispherical $>$ transition $\mathrm{B}>$ cylindrical.

The pits are more profound (around 3 times) than wide and growing preferably in depth. It is noted that the higher exposure time, the greater the depth of pits even between different morphologies of pits (irregular: $27.79 \mu \mathrm{m}$ and conic: $19.60 \mu \mathrm{m}$ in 216 hours and irregular: 7.15 $\mu \mathrm{m}$ in 120 hours and 216 hours in $27.79 \mu \mathrm{m}$ ) and constant width.

The evolution kinetics of pitting corrosion has similarities to austenitic stainless steel, while the material in the state as-received, with microstructural characteristics induced by mechanical deformation, type: twinned that formed a barrier in pits formation.

However, the treated material forming the corrosion process is facilitated by making a channel sensitization induction of corrosion by extending the grain boundaries with increasing volume fraction of chromium carbides precipitated and their circular morphology.

\section{Conclusions}

The experimental methodology was enhanced austenitic stainless steels ABNT $310 \mathrm{~S}$ to evaluate the classification, distribution and morphology of pits in alloy liable to vary in composition and heat treatment. The alloys after sensitization heat treatments showed formation of chromium carbides at grain boundaries and inner specifically stainless steel $310 \mathrm{~S}$ shown in greater quantity and coarser microstructure contributing to increased pitting corrosion, as the data obtained in surface analysis and profiles.

After the corrosion tests at different conditions under salt spray, it was observed that the aspect ratio of pits for stainless $310 \mathrm{~S}$ in the state as received and treated, the geometry corresponds to circular. The $310 \mathrm{~S}$ stainless steel showed higher values and the same trend for the statistical parameters pits, but the alloy was lower localized corrosion resistance than stainless steel 304, apparently by the difference in the microstructure and chemical composition.

On superficial analysis in stainless steel $310 \mathrm{~S}$ it was showed up as received the following order in the morphology of pits: hemispheric $>$ transition region $\mathrm{A}>$ transition region $\mathrm{B}>$ irregular $>$ conic, and the pits are present in larger amounts in hemispheric and transition region $\mathrm{A}$. The pits are wider than deep, preferably grow in width. The cylindrical pits were not observed in the system. 
When the alloy is treated at each exposure time, it has the same order in the amount of pits: transition region $\mathrm{B}>$ hemispheric $>$ transition region $\mathrm{A}>$ conical > irregular, particularly the pits are deeper than wide. Significant changes in morphology and size distribution of pits on stainless steel when treated $310 \mathrm{~S}$ are correlated to the role of chromium carbide precipitates, in particular the amount and morphology.

Through the median size of the width and depth of pits it was proved the following order: irregular $>$ conical $>$ transition region A $>$ Hemispheric $>$ transition region B. 310 S stainless steel in the state as received and processed, the growth rate of pits, specifically the width and depth are different, the last of which appears to be larger and change with time of exposure, thus showing the high values in the irregular pits and distribution in large amounts of pitting in the transition region A and B, sometimes almost conical and hemispherical.

After Salt Spay test, 310 S austenitic stainless steel sensitized by means of different heat treatments has exhibited similar microstructures and similar pits morphological characteristics. Nucleation rates and growth may be associated with quantity and distribution of chromium carbides. In this sense, condition I and II are the most susceptible to pitting, in particular the first one. In these two conditions, the pits are nucleated in grains and grain boundaries, while in condition III, pits are preferentially nucleated in boundaries of small grains. Then, the pits grow more rapidly in depth than in width being able to carry out a partial or total separation of grains. Pits are mainly hemispherical, near-hemispherical, near-conical and nearcylindrical. However, irregular pits are also important because they are the deepest ones, which can initiate a stress-corrosion crack, thus transforming one type of localized attack into another.

\section{Acknowledgements}

This research has been supported by FUNDUNESP (process 01258/08-DFP) and CNPq (process 305224/2004-2).

\section{Author details}

Rosinei Batista Ribeiro ${ }^{1,3^{*}}$, Gilbert Silva ${ }^{2}$, Antônio Henriques Jr. Araujo ${ }^{1}$,

Nelson Tavares Matias ${ }^{1,3}$, José Wilson De Jesus Silva ${ }^{1,3}$ and

Bianca Siqueira Martins Domingos ${ }^{2}$

*Address all correspondence to: rosinei.ribeiro@pq.cnpq.br

1 Universidade do Estado do Rio de Janeiro - Faculdade de Tecnologia - FAT-UERJ - Campus Regional de Resende/RJ, Brazil

2 Universidade Federal de Itajubá - UNIFEI - Itajubá/MG, Brazil

3 Faculdades Integradas Teresa D'Ávila - FATEA - Lorena/SP, Brazil 


\section{References}

[1] H.K.D.H. Bhadeshia, R.W.K. Honeycombe, Steels, Microstructure and Properties, $3^{\text {rd }}$ Ed., Butterworth-Heinemann Apr. 1, 2011 - Technology \& Engineering 360 pages.

[2] P. Marcus, V. Maurice, H.-H. Strehblow, Localized corrosion (pitting): A model of passivity breakdown including the role of the oxide layer nanostructure, Corrosion Science, Volume 50, Issue 9, September 2008, Pages 2698-2704.

[3] A. Pardo, M.C. Merino, A.E. Coy, F. Viejo, R. Arrabal, E. Matykina, Pitting corrosion behavior of austenic stainless steels - combining effects $\mathrm{Mn}$ of and Mo additions, Corrosion Science, Vol. 50, Issue 6, Jun. 2008, pp. 1796-1806.

[4] L. Speckert, G.T. Burstein, Combined anodic/cathodic transient currents within nucleating pits on Al-Fe alloy surfaces, Corrosion Science Volume 53, Issue 2, Feb. 2011, Pages 534-539

[5] Z.Y. Liu, X.G. Li, Y.F. Cheng, Understand the occurrence of pitting corrosion of pipeline carbon steel under cathodic polarization, Electrochimica Acta, Volume 60, 15 January 2012, Pages 259-263

[6] Zixue Su, Georg Hähner and Wuzong Zhou, Investigation of the pore formation in anodic aluminium oxide, J. Mater. Chem., 2008, 18, pp. 5787-5795.

[7] A. Pardo, M.C. Merino, A.E. Coy, R. Arrabal, F. Viejo, E. Matykina, Corrosion behaviour of magnesium/aluminium alloys in $3.5 \mathrm{wt}$ \% NaCl, Corrosion Science, Vol. 50, Issue 3, Mar. 2008, pp. 823-834.

[8] Guocheng LÜ, Haidong CHENG, Chunchun XU, Zonghu HE, Effect of Strain and Chloride Concentration on Pitting Susceptibility for Type 304 Austenitic Stainless Steel, Chinese Journal of Chemical Engineering, Volume 16, Issue 2, April 2008, Pages 314-319

[9] Hosni M. Ezuber, Influence of temperature and thiosulfate on the corrosion behavior of steel in chloride solutions saturated in $\mathrm{CO}_{2}$ Materials \& Design, Volume 30, Issue 9, October 2009, Pages 3420-3427.

[10] Ghahari, S M; Krouse, D P; Laycock, N J; Rayment, T; Padovani, C; Suter, T; Mokso, R; Marone, F; Stampanoni, M; Monir, M; Davenport, A J, Pitting corrosion of stainless steel measuring and modelling pit propagation in support of damage prediction for radioactive waste containers, Corrosion Engineering, Science and Technology, Volume 46, Number 2 April 2011, pp. 205-211(7).

[11] H.W. Pickering, The role of electrode potential distribution in corrosion processes, Mater. Sci. Eng. A198, 1995, pp. 213-223.

[12] G. Engelhardt, M. Urquidi-Macdonald, D.D. Macdonald, A simplified method for estimating corrosion cavity growth rates, Corros. Sci. 39, 1997, pp. 419-441. 
[13] Standard Guide for Examination and Evaluation of Pitting Corrosion, ASTM G46-94, 1999, pp. 169-175

[14] E.N. Codaro, R.Z. Nakazato, A.L. Horovistiz, L.M.F. Ribeiro, R.B. Ribeiro, L.R.O. Hein, Mater. Sci. Eng. A 341, 2003, pp. 202-210.

[15] T. Huang, G.S. Frankel, Influence of grain structure on anisotropic localized corrosion kinetics of AA7XXX-T6 alloys, Corros. Eng. Sci. \& Technol. 41, 2006, pp. 192-199.

[16] Standard Specification for Chromium and Chromium-Nickel Stainless Steels plate, sheet, and strip for pressure vessels and for general applications, ASTM A240/ A240M-09a, 2009, pp. 1-13.

[17] Standard Practice for Operating Salt Spray (Fog) Apparatus, ASTM B117-11, 2011, p. $1-10$.

[18] W.S. Rasband, ImageJ, U. S. National Institutes of Health, Bethesda, Maryland, USA, http://rsb.info.nih.gov/ij/, 1997-2013.

[19] Marinalda C. Pereira, José W. J. Silva, Heloisa A. Acciari, Eduardo N. Codaro, Luis R. O. Hein, Morphology Characterization and Kinetics Evaluation of Pitting Corrosion of Commercially Pure Aluminium by Digital Image Analysis, Materials Sciences and Applications, 2012, 3, 287-293.

[20] G. Krauss, Steels, Heat treatment and processing principles, ASM international, Ohio, USA, 2000, Chap. 12, pp. 351-375.

[21] Giuseppe Carlo Marano, Rita Greco, Sara Sgobba, A comparison between different robust optimum design approaches: Application to tuned mass dampers, Probabilistic Engineering Mechanics, Volume 25, Issue 1, January 2010, Pages 108-118

[22] S.S.M. Tavares, V. Moura, V.C. da Costa, M.L.R. Ferreira, J.M. Pardal, Microstructural changes and corrosion resistance of AISI $310 \mathrm{~S}$ steel exposed to $600-800{ }^{\circ} \mathrm{C}$, Materials Characterization, Volume 60, Issue 6, June 2009, Pages 573-578

[23] C. García, F. Martín, Y. Blanco, M.L. Aparicio, Effect of ageing heat treatments on the microstructure and intergranular corrosion of powder metallurgy duplex stainless steels, Corrosion Science, Volume 52, Issue 11, November 2010, Pages 3725-3737

[24] A. Iversen, B. Leffler, 3.04 - Aqueous Corrosion of Stainless Steels, Shreir's Corrosion, Volume 3, 2010, Pages 1802-1878

[25] S.S.M. Tavares, V.G. Silva, J.M. Pardal, J.S. Corte, Investigation of stress corrosion cracks in a UNS S32750 superduplex stainless steel, Engineering Failure Analysis, In Press, 2013

[26] Ribeiro, R. B. ; Codaro, E. N. ; Hein, L. R. O. ; Rosa, J. L. ; Mariotto, S. F. F. ; Meraz, E. A.. Estudo da corrosão localizada em aço inoxidável austenítico ABNT $310 S$ submetido à exposição em névoa salina. Matéria (UFRJ), v. 13, p. 1024-1030, 2009. 
[27] Gravalos, Márcio Tadeu; Martins, Marcelo; Diniz, Anselmo Eduardo and MEI, Paulo Roberto. Influência da rugosidade na resistência à corrosão por pite em peças torneadas de aço inoxidável superaustenítico. Rem: Rev. Esc. Minas [online]. 2010, vol.63, n. 1, pp. 77-82.

[28] Veroli, Alyne Bernardes. Avaliação da resistência ao desgaste de aços inoxidáveis endurecíveis por precipitação nitretados. Dissertação de Mestrado. São Carlos: UFSCar, 2012. 83 p. 